\title{
Osmo-Dehydrated Functional Product Containing Fructo- oligosaccharides: Physical, Chemical and Sensorial Characteristics
}

\author{
Mariana Buranelo Egea ${ }^{* 1}$, Dionísio Borsato ${ }^{2}$, Rui Sérgio dos Santos Ferreira da Silva ${ }^{2}$ and \\ Fabio Yamashita ${ }^{2}$ \\ ${ }^{I}$ Departamento de Engenharia Química; Universidade Federal do Paraná; St. Francisco H. dos Santos s/no; C. P.: \\ 19011; 81531-980; Curitiba - PR - Brasil. ${ }^{2}$ Departamento de Ciência e Tecnologia de Alimentos; Universidade \\ Estadual de Londrina; C.P.: 6001; 86051-990; Londrina - PR - Brasil
}

\begin{abstract}
The objective of the present study was to develop a functional product from the osmo-dehydrated Fuji apple incorporating FOS with acceptable physical, chemical and sensorial characteristics and potential for commercialscale production. Some treatments were discarded due to texture and water activity that did not reach the desired quality parameters. The products submitted to the osmo-dehydration treatments presented a greater vitamin $C$ loss. All the treatments obtained sensory scores of 6 in a 9 points scale for all the attributes, except the crispness, indicating good acceptance. The sensory scores and incorporated FOS quantities indicated that the osmodehydrated apple products have potential for commercial-scale production.
\end{abstract}

Key words: sensory analysis, functional product, apple, combined conservation methods

\section{INTRODUCTION}

Brazil is a large producer of fruits but the lack of suitable transport system, packing and storage results in huge post-harvest losses (Gomes 2007). Dehydration is an alternative to make fruits available for a longer period of time, aggregate value to the product and reach another type of consumer market (Meloni 2003, Rauolt-Wack 1994, Vega-Mercado et al. 2001).

Osmo-dehydration favors tissue softness with less shrinkage during the drying because the dehydration solute is impregnated during the processing. This means that with greater solids entry, there is less resistance to the product compression compared with the non-osmodehydrated product (Lewicki and Lukaszuk 2000, Rauolt-Wack 1994). Sanjinéz-Argandoña (2005) studied guava dehydration by osmo-convection (osmo-dehydration and convective drying) and observed that high drying temperatures modified the product texture, which became more rigid and brown in color that damaged the quality of the end-product. Other authors also studied the osmotic dehydration in combination with convective drying for the product development (Azevedo and Jardine 2000, Elias et al. 2008, Giovanelli et al. 2002, Pereira et al. 2003, Tan et al. 2001, Torreggiani and Bertolo 2001).

Consumption of pre-biotic foods has increased recently because of the appeal of their functionality and the well-being they generate for the individual (Gibson and Roberfroid 1995). In this context, the oligosaccharides are nondigestible carbohydrates have various physiological functions (Búrigo et al. 2007, Qiang

\footnotetext{
*Author for correspondence: mariegea@lmferreira.com
} 
et al. 2009). Among the functional oligosaccharides, short chain fructooligosaccharides (FOS) have been used with increasing frequency as food additives with the possible benefits, including the support for the beneficial gastrointestinal flora and reduction of infectious diarrhea (Rhoades et al. 2006). The fructo-oligasaccharides are known for their ability to stimulate the growth of Bifidobacterium and Lactobacillus and to inhibit that of potentially pathogenic bacteria, such as Enterobacteria, Clostridium and Salmonella (Mussatto and Mancilha 2007, Passos and Park 2003, Qiang et al. 2009).

The objective of the present study was to develop a functional product from the osmo-dehydrated Fuji variety apple with incorporated fructooligosaccharides (FOS) that should have acceptable physical, chemical and sensorial characteristics with potential for commercial scale production.

\section{MATERIAL AND METHODS}

The Fuji variety apple was chosen due to its lower average annual price ( $\$$ \$1.56) and good availability in the Brazilian market (81.3\%) (Cetnarski Filho et al. 2008). Moreover, when compared with the Gala and Golden Red varieties, it has less soluble solids (12.4 ${ }^{\circ}$ Brix against 14.7 and $16.1^{\circ}$ Brix, respectively).

Fuji variety apples were purchased from the local market in Londrina city, PR, Brazil, and were selected by homogeneity of size, shape and ripeness. They were washed with neutral detergent, disinfected with 50 ppm sodium hypochlorite solution (Carnelossi et al. 2005) and cut in slices approximately $5 \mathrm{~mm}$ thick, horizontal to the endocarp (crosswise to the axle) without removing the peel (mass transfer in infinite plate). The seeds were removed with the core using a coconut perforator. The slices were immersed in 1 $\%$ citric acid solution (w/v) at $24-25^{\circ} \mathrm{C}$ for 15 minutes (Matusek et al. 2008) before osmodehydration. Osmo-dehydration was carried out with Beneo Orafti ${ }^{\circledR}$ P95 (Tienen, Belgium) at 1:10 fruit:solution ratio. Table 1 shows the osmotic and control treatments carried out on the apple slices.

The apple slices were dried in a chamber (Tecnal TE model 394/3, Piracicaba, Brazil) with $12 \mathrm{~m}^{3} \cdot \mathrm{h}^{-1}$ air circulation and $\pm 2^{\circ} \mathrm{C}$ accuracy. The convective drying experiments were carried out at 50,60 and $70^{\circ} \mathrm{C}$ until the product reached moisture below 25 $\%$, as recommended in ANVISA CNNP $\mathrm{n}^{\circ} 12$ (BRASIL 1978) for the dehydrated products and to guarantee the microbiological, physical, chemical and sensory stability of the product. The color of the samples was determined by the CIELAB system parameters $\mathrm{L}^{*}, \mathrm{a}^{*}$ and $\mathrm{b}^{*}$, where $\mathrm{L}^{*}$ defined the luminosity $\left(\mathrm{L}^{*}=0\right.$ black and $\mathrm{L}^{*}=100$ white) and $\mathrm{a}^{*}$ and $\mathrm{b}^{*}$ determined the chromaticity $\left(+a^{*}=\right.$ red and $-a^{*}=$ green, $+b^{*}=$ yellow and $-b^{*}$ = blue). The cylindrical coordinated $\mathrm{H}^{*}$ and $\mathrm{C}^{*}$ were calculated according the equations 1 and 2 , respectively, where $\mathrm{C}^{*}$ defined the chromaticity (color intensity, the chromaticity values close to zero determine neutral colors and those nearer to sixty determine vivid colors), and $\mathrm{H}^{*}$ was the tone, zero $=$ red, $90=$ yellow, $180=$ green and $270=$ blue) (Hunterlab, 1996).

$$
\begin{aligned}
& \mathrm{H}^{*}=\arctan \left(\frac{\mathrm{b}^{*}}{\mathrm{a} *}\right) \\
& \mathrm{C}^{*}=\sqrt{\mathrm{a}^{* 2}+\mathrm{b}^{* 2}}
\end{aligned}
$$

Water activity was determined by an AQUALAB water activity meter model $\mathrm{Cx}-2$ (Decagon, Pullman, USA) at $25^{\circ} \mathrm{C}$.

The maximum rupture force and the probe penetration distance were determined using a TAXT2i model texturometer (Stable Micro System, Surrey, United Kingdom) with a 1/4" diameter probe $(\mathrm{P} / 0.25 \mathrm{~S})$. The stipulated conditions were $1.0 \mathrm{~mm} / \mathrm{s}$ pre-test speed, $1.0 \mathrm{~mm} / \mathrm{s}$ test speed, $10.0 \mathrm{~mm} / \mathrm{s}$ post-test speed, $10.0 \mathrm{~mm}$ piston penetration distance. Ten samples were analyzed from each treatment, each with three penetrations. Vitamin $\mathrm{C}$ content was analyzed by the 43.064 method of AOAC (1994), modified by Benassi and Antunes (1988) where the standard extraction solution (metaphosphoric acid solution) was substituted by an oxalic acid solution. The fructo-oligosaccharides in the samples were quantified using a Megazyme ${ }^{\circledR}$ (Method AOAC 999.03/ Method AACC 32.32) enzymatic kit (KFRUC 5/2008, Bray, Ireland).

The sensory evaluation and the purchase intent of the osmo-dehydrated apple slices containing functional ingredient (FOS) was carried out using an affective test (nine-point hedonic scale with "9" as "I like it very much" and "1" as "I didn't like it at all") and, respectively, with 50 panelists, 
including the students, staff and professors from the State University of Londrina. Necessary approval was obtained from the Ethics Committee for Research with Human Beings (PF173/09). The physical and chemical analyses carried out previously were used as the parameter to choose the treatments used in these sensory analysis.
All analyses were carried out in triplicate, except for the color analysis (six repetitions). Analysis of variance and the means test (Tukey) were performed using the statistical software Statistica ${ }^{\circledR}$ 7.0 (StatSoft). Level of significance was set at $\mathrm{p}<0.05$ for the null hypothesis.

Table 1 - Treatments submitted to convective drying at 50,60 and $70^{\circ} \mathrm{C}^{*}$.

\begin{tabular}{cl}
\hline Code & Treatment \\
\hline MC & Control Fuji Apple slices \\
MA & Acidified Fuji Apple slices \\
MO45 & Fuji Apple slices osmotically dehydrated with $40 \%[\mathrm{FOS}]$ at $45^{\circ} \mathrm{C}$ \\
MO60 & Fuji Apple slices osmotically dehydrated with $40 \%[\mathrm{FOS}]$ at $60^{\circ} \mathrm{C}$ \\
MCJ & Commercial dehydrated apple (Jasmine ${ }^{\circledR}$ brand) \\
\hline * D50, D60 and D70 were added to the code, when temperatures 50,60 and $70^{\circ} \mathrm{C}$ were used, respectively.
\end{tabular}

\section{RESULTS AND DISCUSSION}

\section{Color}

Tables 2 and 3 show the color parameters of the apple slice samples before and after convective drying at different temperatures. The commercial product $(\mathrm{MCJ})$ showed $\mathrm{L}^{*}$ values of $71.76 \pm 3.37$, $\mathrm{a}^{*}$ of $7.89 \pm 1.18$ and $\mathrm{b}^{*}$ of $26.76 \pm 2.40$.

The low values of the $a^{*}$ parameter demonstrated its lesser importance in the apple color assessment before drying, because neither the red nor green colors were very pronounced in the initial product (Pereira et al. 2006). When this value was positive, an accentuated red color was observed in the apple slices.

The apple processing (osmotic and drying) increased the $b^{*}$ parameter probably due to the pigments concentration since the solute creates a protective barrier that prevents the pigments exit, and consequently, color loss by the fruit (Pereira et al. 2006).

The $\mathrm{L}^{*}$ (luminosity) is the most significant parameter that indicates enzymatic browning during the process. Valente (2007) and Tan et al. (2001) reported that longer osmotic treatments resulted in greater alterations in the fruit. Figure 1 shows the initial and final luminosity $\left(\mathrm{L}^{*}\right)$ parameter for all the treatments carried out on the apple slices. The Tukey's test and the t-test were carried out for the intra- and inter-treatments in the initial and final periods to determine the significant differences (at the 5\% level of significance).

Table 2 - Initial and final color parameters of control and acidified apple slices submitted to convective drying at 50 , 60 and $70^{\circ} \mathrm{C}$.

\begin{tabular}{ccccc}
\hline Treatment & \multicolumn{2}{c}{ Initial } & \multicolumn{2}{c}{ Final } \\
\cline { 2 - 5 } & $\mathbf{a}^{*}$ & $\mathbf{b}^{*}$ & $\mathbf{a}^{*}$ & $\mathbf{b}^{*}$ \\
\hline MCD50 & $2.23 \pm 0.65$ & $28.47 \pm 1.89$ & $8.52 \pm 1.79$ & $36.91 \pm 2.57$ \\
MCD60 & $2.73 \pm 0.87$ & $24.27 \pm 1.97$ & $7.02 \pm 0.79$ & $38.84 \pm 1.69$ \\
MCD70 & $-0.14 \pm 0.27$ & $22.40 \pm 1.43$ & $3.37 \pm 1.12$ & $31.12 \pm 2.85$ \\
MAD50 & $1.54 \pm 0.43$ & $19.69 \pm 2.58$ & $9.11 \pm 1.04$ & $38.04 \pm 1.72$ \\
MAD70 & $0.97 \pm 0.45$ & $23.84 \pm 1.37$ & $7.95 \pm 1.69$ & $36.53 \pm 1.04$ \\
MO45D50 & $-0.45 \pm 0.24$ & $23.23 \pm 2.42$ & $5.31 \pm 1.42$ & $30.96 \pm 1.99$ \\
MO45D60 & $1.70 \pm 0.24$ & $24.58 \pm 1.35$ & $6.49 \pm 1.15$ & $26.05 \pm 1.15$ \\
MO45D70 & $-0.12 \pm 0.42$ & $20.25 \pm 0.96$ & $5.68 \pm 2.17$ & $31.81 \pm 1.43$ \\
MO60D50 & $0.31 \pm 0.10$ & $25.44 \pm 0.98$ & $8.32 \pm 0.83$ & $31.76 \pm 0.89$ \\
MO60D60 & $5.17 \pm 1.34$ & $19.9 \pm 2.63$ & $4.58 \pm 1.13$ & $24.82 \pm 2.06$ \\
MO60D70 & $-1.11 \pm 0.82$ & $16.57 \pm 1.14$ & $4.12 \pm 0.94$ & $23.45 \pm 0.48$ \\
& $3.37 \pm 0.92$ & $21.53 \pm 0.46$ & $7.40 \pm 0.89$ & $26.80 \pm 1.34$ \\
\hline
\end{tabular}


Table 3 - Color parameters calculated for osmotically dehydrated Fuji apples submitted to drying at 50, 60 and $70^{\circ} \mathrm{C}$.

\begin{tabular}{|c|c|c|c|c|c|}
\hline \multirow{2}{*}{ Treatments } & \multicolumn{2}{|c|}{ Initial } & \multicolumn{2}{|c|}{ Final } & \multirow[t]{2}{*}{$\Delta \mathbf{E}$} \\
\hline & $\mathbf{H}$ & $\mathbf{C}$ & $\mathbf{H}$ & $\mathbf{C}$ & \\
\hline MCD50 & 1.49 & 28.56 & 1.35 & 37.88 & 10.53 \\
\hline MCD60 & 1.46 & 24.82 & 1.39 & 39.47 & 15.76 \\
\hline MCD70 & -1.56 & 22.39 & 1.46 & 31.30 & 11.69 \\
\hline MAD50 & 1.49 & 19.75 & 1.34 & 39.11 & 20.44 \\
\hline MAD60 & 1.53 & 23.85 & 1.36 & 37.38 & 15.40 \\
\hline MAD70 & -1.55 & 23.23 & 1.40 & 31.41 & 17.46 \\
\hline MO45D50 & 1.50 & 24.64 & 1.33 & 29.85 & 5.58 \\
\hline MO45D60 & -1.56 & 20.25 & 1.39 & 32.83 & 15.02 \\
\hline MO45D70 & 1.55 & 25.44 & 1.31 & 32.83 & 10.26 \\
\hline MO60D50 & 1.32 & 20.56 & 1.39 & 25.24 & 7.47 \\
\hline MO60D60 & -1.50 & 16.61 & 1.40 & 23.80 & 8.69 \\
\hline MO60D70 & 1.42 & 21.79 & 1.30 & 27.80 & 6.94 \\
\hline
\end{tabular}

$\mathrm{C}$ is the chromaticity; $\mathrm{H}$ is the tone.

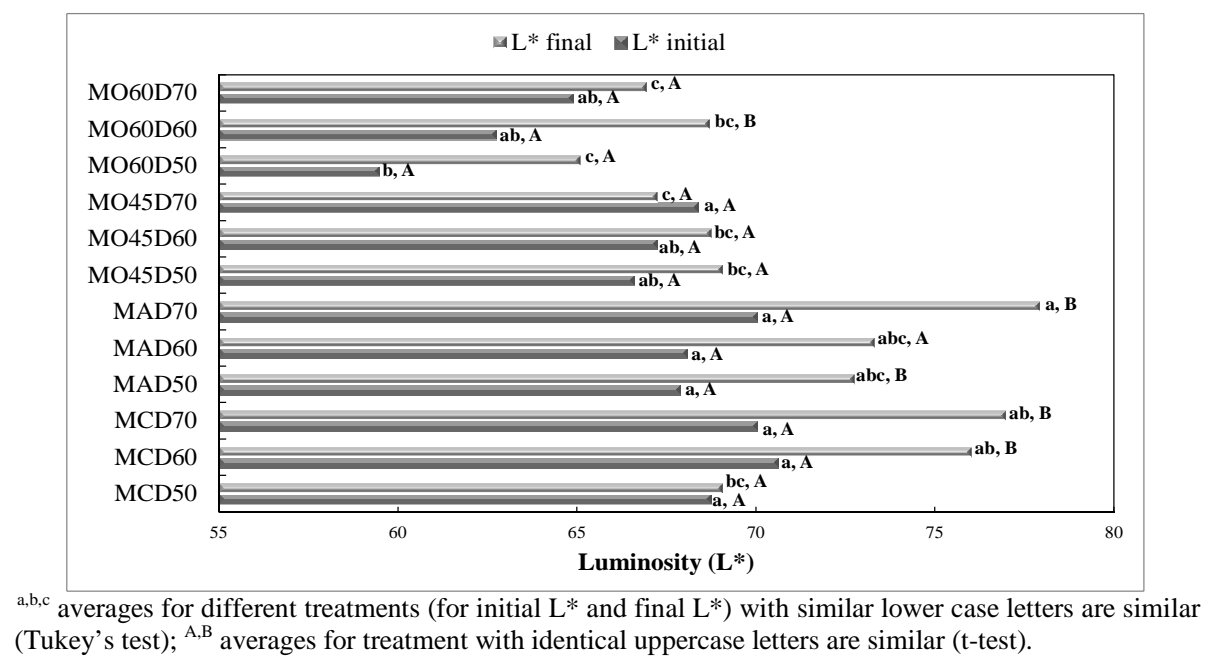

Figure 1 - Parameter of luminosity $\left(\mathrm{L}^{*}\right)$ of Fuji apple slices submitted to osmo-convective drying.

The initial and final $\mathrm{L}^{*}$ values of the M60D50 apple slices treatment were lower and different from all the other treatments studied. The initial and final $\mathrm{L}^{*}$ values of the MCD60, MCD70, MAD50, MAD70 and MO60D60 apple slices treatments were significantly different. The decrease in $\mathrm{L}^{*}$ value of the osmo-dehydrated apple slices compared with the fresh product has been reported by Germer et al. (2010).

According to Pomeranz and Meloan (1994), the chromaticity $\left(\mathrm{C}^{*}\right)$ indicates the color saturation or intensity, describing, for example, how brick red differs from tomato red, and the $\mathrm{H}^{*}$ tone is the color characteristic described by the words green, blue, red and yellow, and these two parameters are influenced by the $a^{*}$ and $b^{*}$ values. The chromaticity value of the apple samples performed similarly to that of the $b^{*}$ parameter, because this factor was the most expressive in defining the fruit color and had much higher $b^{*}$ values compared to the $\mathrm{a}^{*}$ parameter.

The tone $\left(\mathrm{H}^{*}\right)$ of the samples compared to the in natura apple slice decreased, indicating the loss of tonality from the fruit, except in the MCD70, MAD70, MO45D60 and MO60D60 treatments that increased, probably due to pigment concentration. The $\Delta \mathrm{E}^{*}$ that indicated the mean difference among the color parameters of the processed and in natura apples (Table 3) was lowest for the MO45D50 (5.58) and highest for the MAD50 (20.44), and the random results indicated that there was no relation with temperatures.

A single condition that favored the product color could not be selected from these observations. The behavior of $\mathrm{a}^{*}, \mathrm{~b}^{*}, \mathrm{C}$ and $\mathrm{H}$ parameters were similar regardless of treatment, except those dried 
at $50^{\circ} \mathrm{C}$. At this temperature, color change and texture were affected, giving the product an elastic characteristic and wet appearance even when the apple slices reached the desired moisture. Thus, Table 4 - Parameters to assess the quality of osmotically dehy

\begin{tabular}{cccccc} 
Table 4 - Parameters to assess the quality of osmotically dehydrated apple slices and with convective drying. \\
\hline Treatment & Water activity $^{*}$ & $\begin{array}{c}\text { Maximum } \\
\text { rupture force }(\mathbf{N})\end{array}$ & $\begin{array}{c}\text { Vitamin C content } \\
(\mathbf{m g} / \mathbf{1 0 0 g} \text { DM })^{* * *}\end{array}$ & $\begin{array}{c}\text { Purchase } \\
\text { intent }\end{array}$ & $\begin{array}{c}\text { Fructan content } \\
(\mathbf{g} / \mathbf{1 0 0 g})\end{array}$ \\
\hline MC & $0.99^{\mathrm{a}} \pm 0.00$ & - & $71^{\mathrm{a}} \pm 2$ & - & - \\
MCD60 & $0.47^{\mathrm{c}} \pm 0.02$ & $7.6^{\mathrm{e}} \pm 2.1$ & - & - & - \\
MCD70 & $0.40^{\mathrm{e}} \pm 0.02$ & $7.1^{\mathrm{e}} \pm 2.5$ & $19^{\mathrm{b}} \pm 1$ & $3.4^{\mathrm{bc}}$ & $1.9^{\mathrm{c}} \pm 0.3$ \\
MA & $0.99^{\mathrm{a}} \pm 0.00$ & - & $73^{\mathrm{a}} \pm 5$ & - & - \\
MAD60 & $0.41^{\mathrm{e}} \pm 0.00$ & $9.3^{\mathrm{e}} \pm 2.8$ & - & - & - \\
MAD70 & $0.39^{\mathrm{e}} \pm 0.02$ & $8.1^{\mathrm{e}} \pm 3.1$ & $20^{\mathrm{b}} \pm 1$ & $3.6^{\mathrm{ab}}$ & $0.8^{\mathrm{c}} \pm 0.4$ \\
MO45D60 & $0.57^{\mathrm{b}} \pm 0.00$ & $16.9^{\mathrm{d}} \pm 3.8$ & - & - & - \\
MO45D70 & $0.53^{\mathrm{bd}} \pm 0.01$ & $22.7^{\mathrm{c}} \pm 5.0$ & $12^{\mathrm{c}} \pm 1$ & $3.0^{\mathrm{cd}}$ & $31.2^{\mathrm{b}} \pm 2.9$ \\
MO60D60 & $0.52^{\mathrm{d}} \pm 0.00$ & $40.1^{\mathrm{b}} \pm 4.1$ & $11^{\mathrm{c}} \pm 3$ & $2.6^{\mathrm{d}}$ & $42.5^{\mathrm{a}} \pm 3.4$ \\
MO60D70 & $0.51^{\mathrm{cd}} \pm 0.00$ & $67.1^{\mathrm{a}} \pm 9.9$ & $9^{\mathrm{c}} \pm 1$ & $3.1^{\mathrm{bcd}}$ & $44.0^{\mathrm{a}} \pm 5.8$ \\
MCJ & $0.39^{\mathrm{e}} \pm 0.02$ & $7.8^{\mathrm{e}} \pm 0.9$ & $20^{\mathrm{b}} \pm 3$ & $4.0^{\mathrm{a}}$ & $2.4^{\mathrm{c}} \pm 1.1$ \\
\hline
\end{tabular}

"Mean and standard deviation of three repetitions, ${ }^{\text {abc }}$ Columns with the same letter do not differ significantly for the Tukey's test $(p>0.05) . \quad$ ** DM - dry-matter, ${ }^{\text {abc }}$ Columns with the same letter do not differ significantly $(p>0.05)$.

\section{Water Activity $\left(\mathbf{A}_{\mathrm{w}}\right)$}

Apple slices submitted to the acidification process and in natura did not differ significantly for the water activity. Fresh fruits, such as the apple, have high water activities $\left(A_{w}>0.90\right)$ that indicate great susceptibility to the microbiological deterioration and enzymatic reactions. When the $A_{w}$ is reduced due to the drying process (below 0.60), the microbiological growth is reduced.The apple slices dried at $70^{\circ} \mathrm{C}$, acidified and dried at 60 and $70^{\circ} \mathrm{C}$ and the commercial ones (MCJ) did not differ significantly. The control samples dried at $60^{\circ} \mathrm{C}$ was the only treatment that differed from the others, probably due to the small inherent differences in total soluble solids content of the raw material.

There was no significant difference in the water activity between 60 and $70^{\circ} \mathrm{C}$ in the convective drying for the treatments submitted to osmotic dehydration (MO45 and MO60). However, the treatment MO45 dried at $60^{\circ} \mathrm{C}$ presented the highest $\mathrm{A}_{\mathrm{w}}$ value for these treatments and an elastic aspect, as occurred in the experiments at $50^{\circ} \mathrm{C}$ that were removed from the study.

According to Chiralt and Talens (2005), the expected changes in the mechanical response provoked by the osmotic processes would be a decrease in the stress-strain relationship, an increase in the elastic character and changes in the failure mode. Thus, if the apple slices processed in the treatments studied were stored in proper packaging and temperatures, they would not the studies continued with apple slices subjected to

drying at 60 and $70^{\circ} \mathrm{C}$. 
chamber at $40^{\circ} \mathrm{C}$. The kiwi slices decreased approximately $28 \%$ in maximum rupture force compared to the initial raw material during the two-hour osmotic dehydration period. The firmness of the kiwi slices increased after the drying. This suggested a weakening of the cell structure while the osmotic exchanges were intense, as a direct reflection on the reduction in slice firmness. Thus, after the drying, the solutes conferred greater rigidity to the cell structure of the fruits and contributed to obtaining slices with greater rupture resistance and instrumental texture with values closer to the fresh fruit.

The parameters in the control samples dried at 60 and $70^{\circ} \mathrm{C}$ showed higher value for the first temperature where there was greater dislocation distance of the probe and elastic aspect compared to drying at $70^{\circ} \mathrm{C}$ (data not shown). This performance also occurred in the acidified treatments dried at 60 and $70^{\circ} \mathrm{C}$. However, this did not occur in the osmo-dehydrated samples because they began the drying process with a greater total solid concentration compared to the control and acidified treatments. The following treatments were selected for sensory assessment based on $\mathrm{A}_{\mathrm{w}}$ and texture parameters: control and acidification dried at $70^{\circ} \mathrm{C}$ (MCD70 and MAD70), treatment MO45 osmotically dehydrated and dried at $70^{\circ} \mathrm{C}$ (MO45D70) and treatment MO60 osmotically dehydrated and dried at 60 and $70^{\circ} \mathrm{C}$ (MO60D60 and MO60S7).

\section{Vitamin C Content}

The apple slices submitted to the acidified treatment showed the highest vitamin $\mathrm{C}$ content of $73 \mathrm{mg} / 100 \mathrm{~g}$ dry matter (Table 4). There was no significant difference compared to the in natura apple or the acidified treatment. The lowest concentration was $9 \mathrm{mg} / 100 \mathrm{~g}$ dry matter for apple slices osmotically dehydrated $(40 \% \quad \% / v$ concentration and $60^{\circ} \mathrm{C}$ temperature) and dried at $70^{\circ} \mathrm{C}$. The control (in natura) and acidified apple slices did not differ for vitamin $\mathrm{C}$ content, but they differed from all the other treatments. The control and acidified treatments dried at $70^{\circ} \mathrm{C}$ lost around $72 \%$ vitamin $\mathrm{C}$ compared to the in natura fruits. Furthermore, they did not differ between each other but they differed from all the other treatments. The three treatments osmotically dehydrated (MO45D70 and MO60 dried at 60 and $70^{\circ} \mathrm{C}$ ) did not differ, but were different from all the other treatments. These treatments presented the highest values of vitamin $\mathrm{C}$ loss compared to the in natura fruit of around $85 \%$. The losses observed during processing were due to the watersoluble nature of vitamin $\mathrm{C}$ that probably solubilized in the osmotic solution (Brandelero 2005). Buchweitz (2005) studied kiwis fruits and reported ascorbic acid losses of in natura fruit and the combination of osmotic dehydration and air drying of around 31, 53 and $67 \%$, respectively.

There was no significant difference among the vitamin $\mathrm{C}$ contents of the treatments MO60D60 and MO60D70 that constituted the same osmotic treatment with different drying temperatures, i.e., the $10^{\circ} \mathrm{C}$ increase in temperature did not affect the vitamin $\mathrm{C}$ degradation. According to Souza Filho et al. (1999), ascorbic acid losses during the osmotic and heating processing were due to water diffusion, and chemical and thermal degradation. However, the ascorbic acid content in the present study for the treatments were higher than that found for the fresh varieties by Feliciano et al. (2010) and by Li et al. (2008).

\section{Sensory Assessment}

To carry out the sensory analysis, a recruitment questionnaire was applied to the panelists to characterize them for their preferences. Among the panelists, $90 \%$ liked the dried fruits and all of them liked foods with fiber sources. The consumption frequency of the dried fruits was considered low, shown by $58 \%$ of the panelists who had never eaten dehydrated apple, $38 \%$ occasionally and $8 \%$ had eaten dehydrated apple moderately. The foods with fiber sources were consumed frequently by $60 \%$, moderately by $28 \%$ and occasionally by $10 \%$ of the panelists.

The preference test was carried out using a ninepoint structured hedonic scale, shown in Figure 2, for the osmotically dehydrated apple slices dried at different temperatures and for the control and acidified treatments and for the commercial product. There was significant difference among the treatments studied for all the attributes analyzed (color, aroma, flavor, crispness and global appearance) (Fig. 3 and Table 5). Table 5 showed that all the treatments received sensory scores greater than 6 (I like it slightly) for all the attributes, except the crispness that indicated that the panelists accepted the product.

The means for the color attribute ranged from 6.2 (MO60D60) to 7.1 (MCJ) and there was significant difference only between these two treatments. Thus, it could be stated that the apple slices dehydrated by the various experimental 
treatments, except MO60D60, presented acceptance similar to the commercial product. The means ranged from 5.7 (MO60D60) to 7.2 (MCJ) for the aroma attribute. The commercial product was not different from the MO45 and MO60 treatments dried at $70^{\circ} \mathrm{C}$ and the control and acidification treatments dried at $70^{\circ} \mathrm{C}$. The aroma acceptance score for the sample M060D60 was the lowest among all the treatments, probably because of the lower temperature and consequently longer drying time needed to reach the required moisture, implying a greater aroma loss during the process.

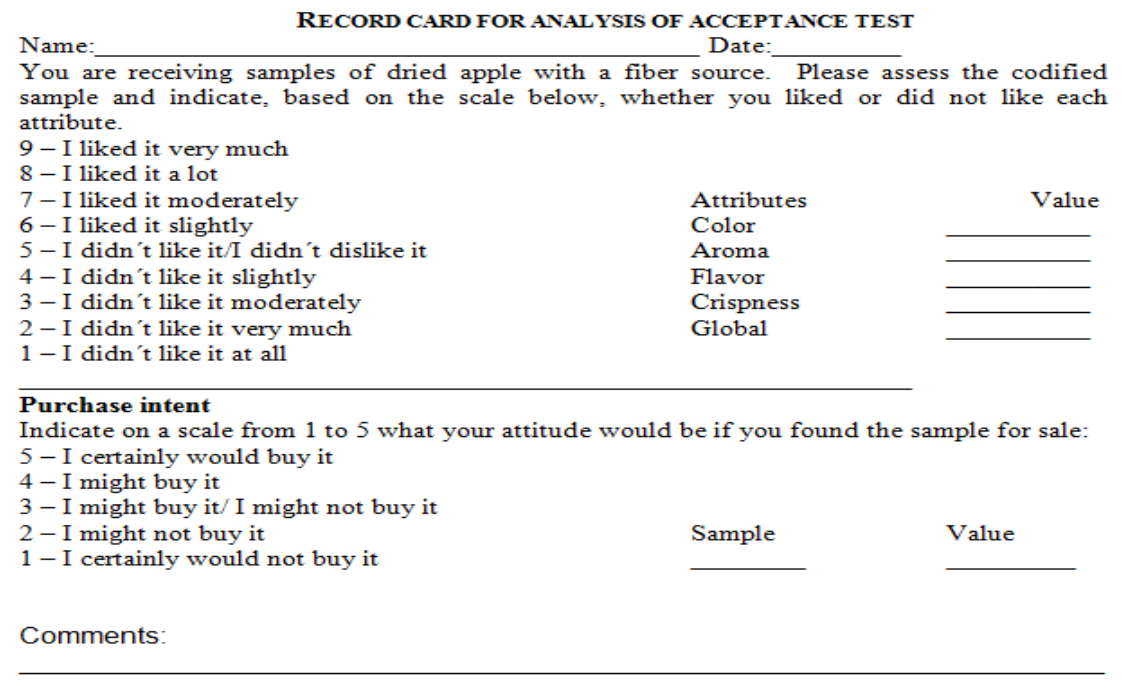

Figure 2 - Record card used in the sensory analysis of the acceptance test and purchase intent of osmotically dehydrated apple slices submitted to convective drying.

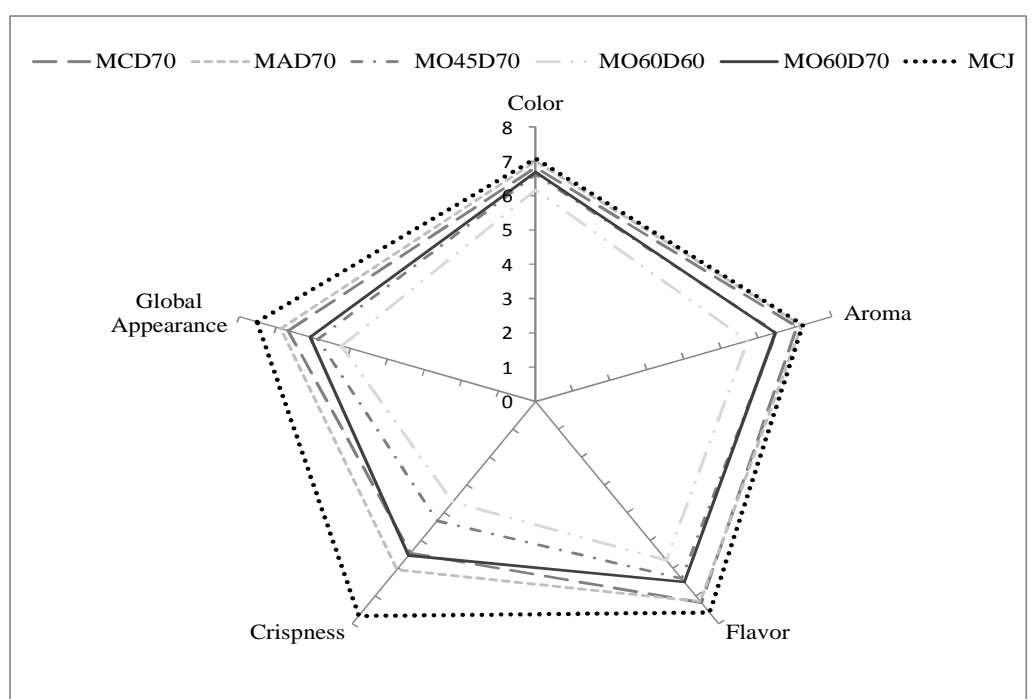

Figure 3 - Acceptability test of osmo-dehydrated apple subjected to convective drying.

Table 5 - Scores of the acceptance tests for apple slices dehydrated by osmo-convective drying.

\begin{tabular}{cccccc}
\hline Treatments & Color & Aroma & Flavor & Crispness & GA \\
\hline MCD70 & $6.8^{\mathrm{ab}}$ & $7.1^{\mathrm{a}}$ & $7.2^{\mathrm{ab}}$ & $5.5^{\mathrm{b}}$ & $6.7^{\mathrm{abc}}$
\end{tabular}




\begin{tabular}{|c|c|c|c|c|c|}
\hline MAD70 & $7.0^{\mathrm{ab}}$ & $7.2^{\mathrm{a}}$ & $7.2^{\mathrm{ab}}$ & $6.1^{\mathrm{b}}$ & $6.9^{\mathrm{ab}}$ \\
\hline MO45D70 & $6.6^{\mathrm{ab}}$ & $6.5^{\mathrm{ab}}$ & $6.4^{b c}$ & $4.3^{c}$ & $5.9^{\mathrm{cd}}$ \\
\hline MO60D60 & $6.2^{b}$ & $5.7^{\mathrm{b}}$ & $5.7^{\mathrm{c}}$ & $3.6^{\mathrm{c}}$ & $5.2^{\mathrm{d}}$ \\
\hline MO60D70 & $6.7^{\mathrm{ab}}$ & $6.5^{\mathrm{ab}}$ & $6.5^{b c}$ & $5.5^{\mathrm{b}}$ & $6.1^{b c d}$ \\
\hline MCJ & $7.1^{\mathrm{a}}$ & $7.2^{\mathrm{a}}$ & $7.6^{\mathrm{a}}$ & $7.7^{\mathrm{a}}$ & $7.5^{\mathrm{a}}$ \\
\hline
\end{tabular}

GA - global appearance.

${ }^{a b c}$ Means in the same column and with the same letter do not differ significantly ( $p>0.05$ ) by the Tukey's test.

Some authors have reported that for osmodehydrated products submitted to convective drying the most important characteristics are flavor and texture that depend on the solute used in preparing the osmotic solution and can generate residual flavor (Brandelero 2005, Córdova 2006). In this case, compared to the control and acidified treatments submitted to drying, the osmodehydrated apples obtained lower means for the attributes assessed. The osmo-dehydrated treatments had difference in flavor acceptance, and the commercial, control and acidified samples dried at $70^{\circ} \mathrm{C}$ presented higher scores than the samples M045 and M060 dried at $70^{\circ} \mathrm{C}$ and M060 dried at $60^{\circ} \mathrm{C}$.

The commercial product obtained the best mean for the crispness attribute (7.7) that was significantly different from the other samples. The lowest means were attributed to the samples MO45 dried at $70^{\circ} \mathrm{C}$ and MO60 dried at $60^{\circ} \mathrm{C}$. The control, acidified and MO60 treatments dried at $70^{\circ} \mathrm{C}$ obtained intermediate crispness means. The samples MO45D70 and MO60D60 presented absence of crispness and stuck on teeth, according to the comments of the panelists on the sensory record cards. This increase in the elastic character probably was caused by the alteration of the middle lamella, alteration of cell wall resistance, changes in air and liquid volume fractions in the sample and changes in sample size and shape (Chiralt and Talens 2005). The MO60D70 was 'brittle' that was classified by some panelists as hardness, confirmed by the texture analysis where this treatment showed the highest maximum rupture force.

The apple slices of the treatment MO60 dried at $60^{\circ} \mathrm{C}$ obtained the lowest mean for the global appearance attribute (5.2) but did not differ significantly from the other osmo-dehydrated treatments. This mean was close to 5 , i.e., the indifference limit on the scale used, indicating that the product was not rejected by the panelists. There was significant difference between the products and the commercial product that presented the highest mean, but did not differ from the control treatment or the acidified treatment dried at $70^{\circ} \mathrm{C}$. Córdova (2006) assessed apple cubes osmotically dehydrated with sucrose and sorbitol and submitted to convective drying. The sensory preference (global appearance) was carried out, and only the treatment osmodehydrated with sucrose was used for the characteristic profile test, because the scores attributed to the samples pre-treated with sorbitol were relative low and sorbitol was not well accepted as dehydrating agent. Blanda et al. (2009) studied osmo-dehydrated strawberries and stored frozen for one month and found that lower temperatures at the osmotic dehydration step had a favorable effect on visual appearance. This trend was reversed in this study when the treatments MO45D70 and MO60D70 were compared, because the higher drying temperature increased the rate of convective drying, reducing the loss of characteristics of the product.

Figure 3 shows that the mean scores for the commercial product were greater for all the attributes assessed. The mean scores for the MO60 apple slices dried at $60^{\circ} \mathrm{C}$ indicated that this treatment was the least preferred by the panelists, also confirmed by the purchase intent (Table 4), so that this sample would not be suitable for commercialization. The purchase intent assessment (Table 4) was applied together with the sensory acceptance test, using a 1 to 5 scale (Fig. 2). The commercial product obtained the highest mean (4.0 - possibly would buy) and did not differ significantly from the acidified treatment dried at $70^{\circ} \mathrm{C}$. The control sample dried at $70^{\circ} \mathrm{C}$ obtained 3.4 (might buy/might not buy) for the purchase intent and did not differ significantly from the M060 dried at $70^{\circ} \mathrm{C}$, with mean 3.1 and MO45 dried at $70^{\circ} \mathrm{C}$ mean 3.0. Among the samples produced by osmotic dehydration and convective drying, the MO60D70 presented the higher means for the sensory attributes and for the purchase intent. 


\section{Fructans Content}

The fructo-oligosaccharides (FOS) content was calculated by the fructans content in the products (Table 4). The FOS was quantified in the fructans as $64.9 \pm 0.2 \mathrm{~g} / 100 \mathrm{~g}$ fructans, and this proportion was used to calculate the FOS concentration present in the samples studied.

The fructans content in dehydrated apple slices produced by convective drying at $70^{\circ} \mathrm{C}$ (control and acidified) and the commercial product did not differ but they differed from the osmotically dehydrated products. The treatments MO60D60 and MO60D70 did not differ in the fructans content because they were submitted to the same temperatures and osmotic concentrations, differing only in the convective drying temperature.

The FOS incorporated in the apple slices by the osmotic treatments ranged from 48.0 to $70.9 \mathrm{~g} / 100$ g. A $50 \mathrm{~g}$ portion of the end-product would not exceed the recommended daily ingestion of this ingredient of up to $30 \mathrm{~g} /$ day. This portion was based on similar products in the market being offered in packages with this amount. The commercial product, control and acidified treatments dried at $70^{\circ} \mathrm{C}$, presented $3.7,3.0$, and $1.2 \mathrm{~g}$ FOS $/ 100 \mathrm{~g}$ product. Since FOS were not added to these treatments and according to the literature apple was not a natural FOS source (Hauly and Moscatto 2002, Voragen 1998), this FOS content probably represented the sugars present in the fruit in natura and the fructans determination was carried out by quantifying the reducing sugars.

\section{CONCLUSION}

The osmo-dehydrated apples can be considered a functional product due to their high FOS content. The product presented acceptable physical, chemical and sensory characteristics and has potential for the commercial-scale production.

\section{REFERENCES}

\section{A.O.A.C. - ASSOCIATION OF OFFICIAL} AGRICULTURAL CHEMISTS. Official methods of analysis. 15nd ed. Washington; 1994.

Azeredo HMC, Jardine JG. Desidratação Osmótica de Abacaxi Aplicada à Tecnologia de Métodos Combinados. Ciênc Tecnol Aliment. 2000; 20 (1): 74-82.
Benassi MT, Antunes AJ. A comparison of metaphosphoric and oxalic acids as extractant solutions for the determination of vitamin $\mathrm{C}$ in selected vegetables. Braz Arch Biol Technol. 1988; 31 (4): 507-513.

Blanda G, Cerretani L, Cardinali A, Barbieri S, Bendini A, Lercker G. Osmotic dehydrofreezing of strawberries: Polyphenolic content, volatile profile and consumer acceptance. Food Sci Technol - LEB. 2009; 42(1): 30-36.

Brandelero RPH, Vieira AP, Telis VRN, Telis-Romero J, Yamashita F. Aplicação de revestimento comestível em abacaxis processados por métodos combinados: isoterma de sorção e cinética de desidratação osmótica. Ciênc Tecnol Aliment. 2005; 25 (2): 285-290.

BRASIL. Ministério da Saúde. Resolução no 12, 30 de março de 1978. Aprova as normas técnicas especiais, do estado de São Paulo, revistas pela CNNP, relativas a alimentos (e bebidas), para efeito em todo o território brasileiro. Diário Oficial da República Federativa do Brasil. Brasília, DF, 24 jul. 1978.

Buchweitz PR. Avaliação da Pré-Secagem de Kiwi (Actinidia deliciosa) complementada por processos convencionais [PhD Thesis]. Campinas, Brasil: Universidade Estadual de Campinas; 2005.

Búrigo T, Fagundes RLM, Trindade EBSM, Vasconcelos HCFF. Efeito bifidogênico do frutooligossacarídeo na microbiota intestinal de pacientes com neoplasia hematológica. Rev Nutr. 2007; 20: 491-497.

Carnelossi MAG, Yaguiu P, Reinoso ACL, Almeida GRO, Lira ML, Silva FG, Jalali VRR. Determinação das etapas do processamento mínimo de quiabo. Hortic Bras. 2005; 23 (4): 970-975.

Cetnarski Filho R, Carvalho RIN, Martin VC. Caracterização da Maça Brasileira Comercializada em Curitiba e Região Metropolitana. Rev Acad, Ciênc Agrár Ambient. 2008; 6 (1): 21-27.

Chiralt A, Talens P. Physical and chemical changes induced by osmotic dehydration in plant tissues. Food Eng. 2005; 67: 167-177.

Córdova, KRV. Desidratação osmótica e secagem convectiva de maça Fuji comercial e industrial [Dissertation]. Curitiba, Brasil: Universidade Federal de Curitiba, 2006.

Elias NF, Berbert PA, Molina MAB, Viana AP, Dionello RG, Queiroz VAV. Avaliação nutricional e sensorial de caqui cv. Fuyu submetida à desidratação osmótica e secagem por convecção. Ciênc Tecnol Aliment. 2008; 28: 322-328.

Feliciano RP, Antunes C, Ramos A, Serra AT, Figueira ME, Duarte CMM, et al. Characterization of traditional and exotic apple varieties from Portugal. Part 1 - Nutritional, phytochemical and sensory evaluation. J Functional Foods. (2010), 2, 35 - 45. 
Franco BDGM, Landgraf M. Microbiologia dos alimentos. São Paulo: Atheneu; 2003.

Germer SPM, Queiroz MR, Aguirre JM, Berbari SAG, Anjos VD. Desidratação osmótica de pêssegos em função da temperatura e concentração do xarope de sacarose. Rev bras eng agríc ambient. 2010; 15 (2): 161-169.

Gibson GR, Roberfroid MB. Dietary modulation of the human colonic microbiota: introducing the concept of prebiotics. J Nutr. 1995; 125: 1401-1412.

Giovanelli G, Zanoni B, Lavelli VE, Nani R. Water sorption, drying and antioxidant properties of dried tomato products. Food Eng. 2002; 52: 135-141.

Gomes RP. Fruticultura brasileira. São Paulo: Nobel; 2007.

Hauly, COM, Moscatto JA. Inulina e Oligofrutose: uma revisão sobre propriedades funcionais, efeito prebiótico e importância na indústria de alimentos. Semina: Tech Ex. 2002; 23: 105-118.

HUNTERLAB. CIE L*a*b* color scale: applications note. Virginia; 1996. [cited 2009 Abr. 10]. Available from: http://www.hunterlab.com/color_theory.php.

Lewicki PP, Lukaszuk A. Effect of osmotic dewatering on rheological properties of apple subjected to convective drying. Food Eng. 2000; 45: 119-126.

Li MJ, Ma FW, Zhang M, Pu F. Distribution and metabolism of ascorbic acid in apple fruits (Malus domestica Borkh cv. Gala), Plant Sci. 2008; 174: 606-612.

Lista de Novos Alimentos/Ingredientes, Substâncias Bioativas e Probióticos [Internet]. 2002 jan [updated 2002 january; cited 2009 march. 23]. Available from: http://www.anvisa.gov.br/alimentos/comissoes/tecno _lista_alega.htm

Matusek A, Czukor B, Merész P. Comparison of sucrose and fructo-oligosaccharides as osmotic agents in apple. Innovative Food Sci. Emerg. Technol. 2008; 9: 365-373.

Meloni PLS. Desidratação de frutas e hortaliças. Fortaleza: Instituto Frutal; 2003.

Mussatto SI, Mancilha IM. Non-digestible oligosaccharides: a review. Carbohyd Polym. 2007; 68: 587-597.

Passos LML, Park YK. Fruto-oligossacarídeos: implicações na saúde humana e utilização em alimentos. Cienc Rural. 2003; 33: 385-390.

Pereira LM, Rodrigues ACC, Sarantópoulos CIGL, Junqueira VCA, Cardello HMAB, Hubinger MD. Vida-de-prateleira de goiabas minimamente processadas acondicionadas em embalagens sob atmosfera modificada. Ciênc. Tecnol. Aliment. 2003; 23: 427-433.

Pereira LM, Ferrari CC, Mastrantonio, SDS, Rodrigues ACC, Hubinger, MD. Kinetic aspects, texture, and color evaluation of some tropical fruits during osmotic dehydration. Dry Technol. 2006; 24 (4): 475484.
Pomeranz Y, Meloan CE. Food Analysis: Theory and Practice. New York: Ed. Chapman and Hall; 1994.

Qiang X, Young Lie C, Qian Bing W. Health benefit application of functional oligosaccharides. Carbohyd Polym. 2009; 77, 435-441.

Raoult-Wack AL. Recent advances in the osmotic dehydration of foods. Trends Food Sci Tech. 1994; 5: 255-260.

Rhoades J, Gibson G, Formentin K, Beer M, Rastall R. Inhibition of the adhesion of enteropathogenic Escherichia coli strains to HT-29 cells in culture by chito-oligosaccharides. Carbohyd Polym. 2006; 64: 57-59.

Sanjinéz-Argandoña EJ, Menegalli FC, Cunha RL, Hubinger MD. Evaluation of total carotenoids and ascorbic acid in osmotic pretreated guavas during convective drying. Ital J Food Sci. 2005; 17: 305314.

Souza Filho MM, Lima JR, Souza ACR, Souza Neto MAE, Costa M. Efeito do branqueamento, processo osmótico, tratamento térmico e armazenamento na estabilidade da vitamina $\mathrm{C}$ de pedúnculos de caju processados por métodos combinados. Ciênc. Tecnol. Aliment. 1999; 19: 211-213.

StatSoft, Inc. (2005). STATISTICA (data analysis software system), version 7.1. Available from: http://www.statsoft.com.

Tan M, Chua KJ, Mujundar AS, Chou SK. Effect of osmotic pre-treatment and infrared radiation on drying rate and color changes during drying of potato and pineapple. Dry Technol. 2001; 19: 2193-2207.

Torreggiani D, Bertolo G. Osmotic pre-treatments in fruit processing: chemical, physical and structure effects. Food Eng. 2001; 49: 247-253.

Valente PPSS. Desidratação Osmótica e Secagem de Abacaxi (Ananás Comosus (L.) Merril), variedade pérola [Dissertation]. Campinas, Brasil: Universidade Estadual de Campinas; 2007.

Veja-Mercado H, Góngora-Nieto MM, BarbosaCánovas GV. Advances in dehydration of foods. Food Eng. 2001; 49: 271-289.

Voragen AGJ. Technological aspects of functional food-related carbohydrates. Trends Food Sci Tech. 1998; 9: 328-335.

Received: June 09, 2011; Revised: December 12, 2011; Accepted: June 08, 2012. 